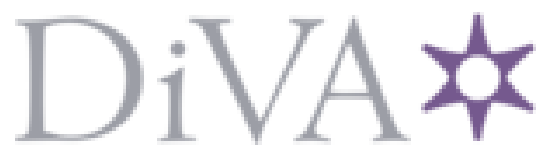

http://www.diva-portal.org

This is the published version of a paper published in The Lichenologist.

Citation for the original published paper (version of record):

Kosuthova, A., Fernández-Brime, S., Westberg, M., Wedin, M. (2016)

Collolechia revisited and a re-assessment of ascus characteristics in Placynthiaceae

(Peltigerales, Ascomycota).

The Lichenologist, 48: 3-13

http://dx.doi.org/doi.org/10.1017/S0024282915000432

Access to the published version may require subscription.

N.B. When citing this work, cite the original published paper.

Permanent link to this version:

http://urn.kb.se/resolve?urn=urn:nbn:se:nrm:diva-2017 


\title{
Collolechia revisited and a re-assessment of ascus characteristics in Placynthiaceae (Peltigerales, Ascomycota)
}

\author{
Alica KOŠUTHOVÁ, Samantha FERNÁNDEZ-BRIME, Martin WESTBERG \\ and Mats WEDIN
}

\begin{abstract}
We investigated the phylogenetic relationships in the cyanolichen family Placynthiaceae to test the current generic delimitations, where the monotypic Collolechia is currently accepted as distinct, based on differences in ascospores, ascus apex characteristics and the leprose thallus. Bayesian and maximum likelihood phylogenetic analyses of two sequence marker datasets confirmed that Collolechia caesia is nested within Placynthium, and should be called Placynthium caesium (Fr.) Jatta. We reassessed the spore and ascus characteristics and showed that Placynthium caesium falls well within the variation in Placynthium and is thus yet another example of a species that differs from close relatives by its crustose-leprose thallus structure.
\end{abstract}

Key words: ascus structure, classification, lichens, morphology, phylogenetics, taxonomy

Accepted for publication 19 August 2015

\section{Introduction}

Lichenization is one of the most important life strategies among fungi in the Ascomycota, but only a comparatively small number of ascomycete lichen fungi (c. 1700 species; Rikkinen 2002) utilize cyanobacteria as photobionts. These lichens may still have a substantial impact on the ecosystems they inhabit by contributing fixed atmospheric nitrogen (Cornelissen et al. 2007; Nash 2008; Campbell et al. 2010), and many cyanobacterial lichens are sensitive to habitat disturbance such as changes in forest age, structure and composition (e.g. Price \& Hochachka 2001; Scheidegger et al. 2002; Hedenås \& Ericson 2008; Fedrowitz et al. 2012) and pollution (e.g. Goward \& Arsenault 2000; Jovan 2008). The largest

A. Košuthová: Department of Cryptogams, Institute of Botany, Slovak Academy of Sciences, Dúbravská cesta 9, Bratislava, 845 23, Slovakia; and Department of Botany and Zoology, Faculty of Science, Masaryk University, Kotlářská 2, Brno, 61137, Czech Republic.

S. Fernández-Brime, M. Westberg and $M$. Wedin (corresponding author): Department of Botany, Swedish Museum of Natural History, P.O. Box 50007, SE-10405 Stockholm, Sweden. Email: mats.wedin@ nrm.se group of lichenized Ascomycota featuring cyanobacteria as the main or sole photobiont is Peltigerales in the Lecanoromycetes (Wiklund \& Wedin 2003; Lumbsch et al. 2004; Wedin et al. 2005; Schoch et al. 2009; Miądlikowska et al. 2014; Rikkinen 2015). Peltigerales are a comparatively recent group of fungi, the ancestor of which diverged from its Lecidealean sister-group in the early Jurassic, and the group diversified towards the end of the Jurassic-early Cretaceous (Prieto \& Wedin 2013). Peltigerales currently includes ten families (Wedin et al. 2007, 2011; Spribille \& Muggia 2013), one of which is Placynthiaceae.

Placynthiaceae comprises comparatively small, flat, rosette-forming, crustose to squamulose-lobate species where the thalli often produce a prothallus (Czeika \& Czeika 2007; Jørgensen 2007). After the recent reclassification of Vestergrenopsis into the newly described family Koerberiaceae (Spribille \& Muggia 2013), Placynthiaceae currently includes two genera: Placynthium with c. 30 species worldwide, and the monotypic Collolechia. Placynthium and Collolechia differ in thallus structure (squamulose vs. leprose-crustose thallus), ascus apex structure (apical caps/sheets vs. apical ring/tube) and spore shape and septation 
(ellipsoid, 1-3 septate in Placynthium vs. elongate, fusiform-acicular, pluriseptate in Collolechia; Jørgensen 2005, 2007). These observations were made on Placynthium nigrum (the type for Placynthium), and Collolechia caesia, respectively (Jørgensen 2005). Several authors, however, have observed tube structures in the asci of Placynthium, including in P. nigrum (Keuck 1977; Rambold \& Triebel 1992; Gilbert \& James 2009; Øvstedal et al. 2009; Wirth et al. 2013). The presence of a tube in Placynthiaceae was pointed out as supporting the sister-group relationship with Collemataceae by Wiklund \& Wedin (2003). Several authors have also noted large variation within the group, including cap- or sheet-like structures, and tube- or ring-structures (Czeika \& Czeika 2007; Spribille \& Muggia 2013).
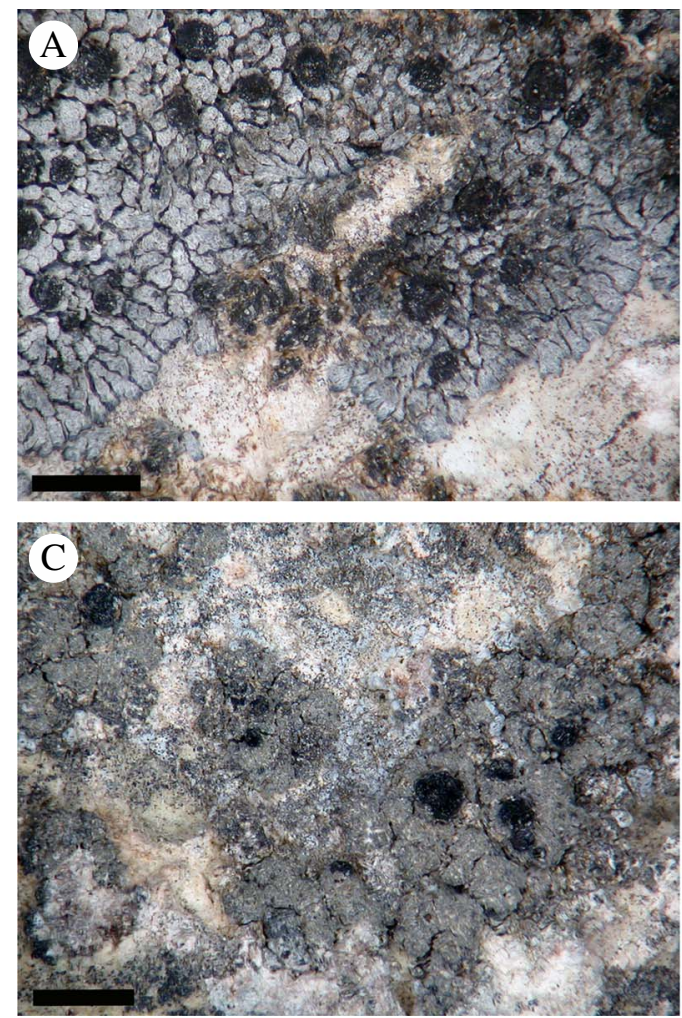

In Scandinavia, Collolechia caesia was for many years confused with Placynthium garovaglioi (Fig. 1). The distinction between the species was clarified by Jørgensen (2005) who showed that in Scandinavia $C$. caesia was known only from a couple of localities on the Baltic island of Gotland, where it had not been collected since 1942. These are northern outposts for a species with an otherwise mainly southern warm-temperate distribution. True Placynthium garovaglioi is not known from Sweden. In 2014, we visited some of the known Swedish localities to assess the status of $C$. caesia, and collected fresh material for DNA-based studies. In this study, we investigated the phylogenetic relationships of Collolechia to test the current generic delimitations in Placynthiaceae. We reinvestigated herbarium material of
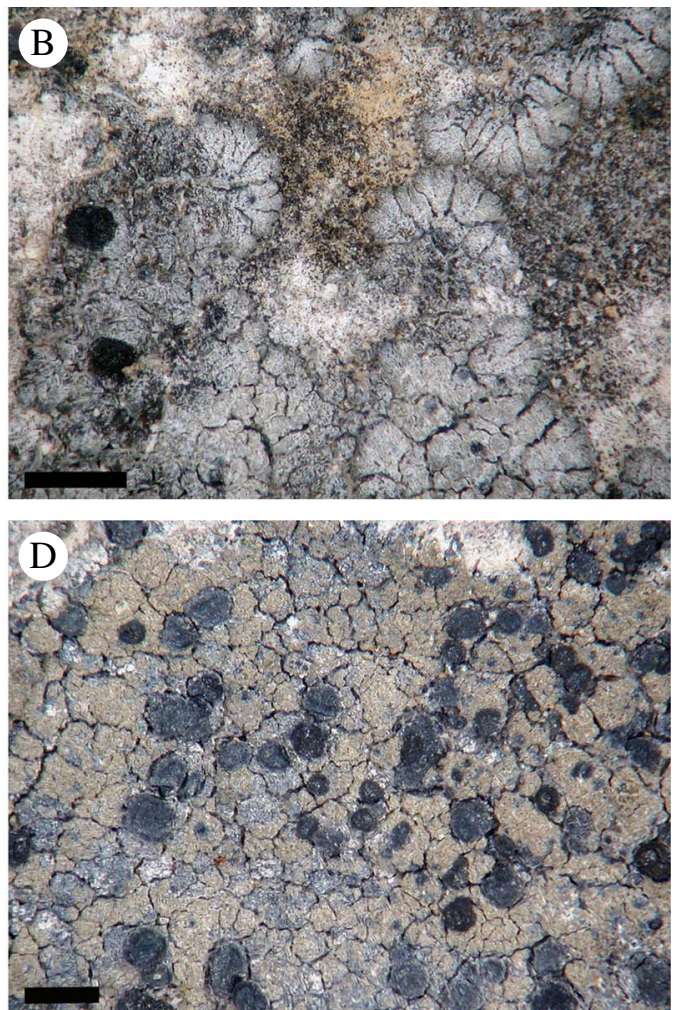

FIG. 1. Morphology of Placynthium garovaglioi and "Collolechia" caesia. A \& B, thallus of Placynthium garovaglioi with distinct marginal lobes; C \& D, "Collolechia" caesia with a leprose thallus lacking marginal lobes. Specimen origin. A, Palice 16564 (SAV); B, Palice 16954 (S); C, Košuthová GOT2 (S); D, Cleve s. n. (S). Scales = 1 mm. In colour online. 
Collolechia and $P$. garovaglioi, and studied the spore and ascus apex characteristics in these species and other selected Placynthiaceae in order to assess variation and potential natural groupings.

\section{Material and Methods}

\section{Taxon sampling and morphological analysis}

Material utilized for the phylogenetic study was mainly freshly collected specimens but was also supplemented with herbarium material from S, SAV and UPS and the personal herbaria of $\mathrm{Z}$. Palice (hb. Palice) and J. Malíček (hb. Malíček). Origin of the material is summarized in Table 1. Asci were studied under oil-immersion, in hand-cut sections of apothecia which were pretreated with and squashed in $\mathrm{KOH}$ and subsequently stained with Lugol's solution.

\section{DNA extraction, amplification and sequencing}

Total DNA was extracted from fresh material and herbarium specimens, and isolated using the DNeasy Plant Mini Kit (Qiagen, Germany) following the manufacturer's instructions. We amplified $\approx 0.6 \mathrm{~kb}$ of the small subunit of the mitochondrial rDNA (mtSSU) and $\approx 1.2 \mathrm{~kb}$ of nuclear mini-chromosome maintenance complex component $7(\mathrm{Mcm} 7)$. Primer combinations used in this study were: mrSSU1 and mrSSU3R (Zoller et al. 1999) for the mtSSU; and MCM7-709for and MCM7-1348rev for the Mcm7 (Schmitt et al. 2009). Symmetric PCR amplifications were performed using Illustra $^{\mathrm{TM}}$ Hot Start PCR beads, according to the manufacturer's instructions. PCR reactions for mtSSU were performed using one of two cycling conditions, depending on what worked with particular samples. The first was $95^{\circ} \mathrm{C}$ for 5 min followed by $35-40$ cycles $\left(95^{\circ} \mathrm{C}\right.$ for $1 \mathrm{~min}, 54^{\circ} \mathrm{C}$ for $50 \mathrm{~s}$, and $72^{\circ} \mathrm{C}$ for $1 \mathrm{~min}$ ), with a final extension of $72^{\circ} \mathrm{C}$ for $8 \mathrm{~min}$. The second was as follows: $95^{\circ} \mathrm{C}$ for $5 \mathrm{~min}$ followed by 4 cycles $\left(95^{\circ} \mathrm{C}\right.$ for $1 \mathrm{~min}, 58^{\circ} \mathrm{C}$ for $1 \mathrm{~min}$, and $72^{\circ} \mathrm{C}$ for $\left.1 \mathrm{~min}\right), 4$ cycles $\left(95^{\circ} \mathrm{C}\right.$ for $1 \mathrm{~min}, 56^{\circ} \mathrm{C}$ for $1 \mathrm{~min}$, and $72^{\circ} \mathrm{C}$ for $1 \mathrm{~min}$ ) and 34 cycles $\left(95^{\circ} \mathrm{C}\right.$ for $1 \mathrm{~min}, 54^{\circ} \mathrm{C}$ for $1 \mathrm{~min}$, and $72^{\circ} \mathrm{C}$ for $1 \mathrm{~min}$ ) with a final extension of $72^{\circ} \mathrm{C}$ for $8 \mathrm{~min}$. For the amplification of the $\mathrm{Mcm} 7$, the following cycling conditions were used: $95^{\circ} \mathrm{C}$ for $5 \mathrm{~min}$ followed by 4 cycles $\left(95^{\circ} \mathrm{C}\right.$ for $1 \mathrm{~min}, 60^{\circ} \mathrm{C}$ for $1 \mathrm{~min}$, and $72^{\circ} \mathrm{C}$ for $1 \mathrm{~min})$, followed by 36 cycles $\left(95^{\circ} \mathrm{C}\right.$ for $1 \mathrm{~min}, 58^{\circ} \mathrm{C}$ for $1 \mathrm{~min}$, and $72^{\circ} \mathrm{C}$ for $1 \mathrm{~min}$ ), with a final extension of $72^{\circ} \mathrm{C}$ for $8 \mathrm{~min}$. After examination by gel electrophoresis, amplification products were purified using ExoSAP-IT (USB Corp., USA). Sequencing of both

TABLE 1. Specimen information and European Nucleotide Archive or GenBank accession numbers for the specimens included in the phylogenetic inference depicted in Figure 2. Sequences represented in bold font were generated in this study.

\begin{tabular}{|c|c|c|c|c|}
\hline \multirow[b]{2}{*}{ Species name } & \multirow[b]{2}{*}{ Isolate no. } & \multirow[b]{2}{*}{ Geographical origin, voucher } & \multicolumn{2}{|c|}{ Accession number } \\
\hline & & & mtSSU & $M c m 7$ \\
\hline Collolechia caesia & AL147 & Turkey, Yazici 1037 (S) & LN876659 & LN876678 \\
\hline C. caesia & AL149 & Sweden, Košuthová GOT1 (S) & LN876660 & LN876679 \\
\hline C. caesia & AL150 & Sweden, Košuthová GOT2 (S) & LN876661 & LN876680 \\
\hline Placynthium asperellum & AL73 & Sweden, Westberg (S F263269) & LN876662 & LN876681 \\
\hline P. flabellosum & AL75 & Norway, Nordin 5666 (UPS) & LN876663 & LN876682 \\
\hline P. garovaglioi & AL146 & Turkey, Yazici 1123 (S) & LN876664 & LN876683 \\
\hline P. garovaglioi & AL148 & Turkey, Yazici 1125 (S) & LN876665 & - \\
\hline P. garovaglioi & AL93 & Slovakia, Palice 16564 (S) & LN876666 & LN876684 \\
\hline P. garovaglioi & AL94 & Slovakia, Palice 16954 (S) & LN876667 & LN876685 \\
\hline P. hungaricum & AL95 & Slovakia, Palice 12746 (hb. Palice) & LN876668 & LN876686 \\
\hline P. hungaricum & AL96 & Romania, Maliček 5625 (hb. Malíček) & LN876669 & LN876687 \\
\hline P. nigrum & AL100 & Czech Republic, Svoboda (S) & LN876670 & LN876688 \\
\hline P. nigrum & AL79 & Sweden, Nordin 5860 (UPS) & LN876671 & LN876689 \\
\hline P. pannariellum & AL81 & Sweden, Nordin 5787 (UPS) & LN876672 & LN876690 \\
\hline P. pulvinatum & AL80 & Sweden, Westberg (S F263268) & LN876673 & LN876691 \\
\hline P. rosulans & AL76 & Sweden, Hermansson 16011 (UPS) & LN876674 & LN876692 \\
\hline P. rosulans & AL77 & Norway, Nordin 5671 (UPS) & LN876675 & LN876693 \\
\hline P. sp. A & AL91 & Spain, Maliček 5616 (hb. Malíček) & LN876676 & LN876694 \\
\hline P. sp. B & AL97 & Albania, Maliček 4273 (hb. Malíček) & LN876677 & LN876695 \\
\hline Collema nigrescens & & & EU982563 & JX992989 \\
\hline Lobaria pulmonaria & & & AY340504 & JX000169 \\
\hline Pannaria rubiginosa & & & AY340513 & JX993042 \\
\hline Scytinium lichenoides & & & DQ923120 & JX993021 \\
\hline Staurolemma omphalarioides & & & EU982560 & JX993043 \\
\hline
\end{tabular}


strands was performed with the Big Dye Terminator technology kit v3.1 (ABI PRISM, USA) using the PCR primers, and the additional internal PCR primers mrSSU2 and mrSSU2R (Zoller et al. 1999).

\section{Sequence alignments and analyses}

Sequence fragments were assembled and edited using Sequencer 4.9 (Gene Codes Corp., Ann Arbor, MI) and Geneious version R8 (http://www.geneious.com, Kearse et al. 2012), and were subjected to BLAST searches (Zhang et al. 2000) for a first identity verification. Sequences were aligned manually in Aliview 1.09 (Larsson 2014). Introns and ambiguously aligned regions (sensu Lutzoni et al. 2000) were delimited manually and excluded from the analyses. We analyzed the mtSSU and $\mathrm{Mcm} 7$ datasets separately using maximum likelihood (ML) as the optimization criterion, with GARLI v.2.0 (Zwickl 2006). Models of molecular evolution were estimated for each locus using the Akaike information criterion correction for finite sample sizes (AICc; Akaike 1973) implemented in jModeltest v.0.1.1 (Guindon \& Gascuel 2003; Posada 2008). The models selected were TVM+I+G (Posada 2003) for mtSSU, TrNef+I (Tamura \& Nei 1993) for $\mathrm{Mcm} 7$ first codon position, F81+I (Felsenstein 1981) for $\mathrm{Mcm} 7$ second codon position, and $\mathrm{K} 80+\mathrm{G}$ (Kimura 1980) for $\mathrm{Mcm} 7$ third codon position. We performed ML searches setting the program to stop after 10000 generations if no improvement of the Ln likelihood $\leq 0.01$ was detected, with a maximum of 500000 . Topological incongruence between the two datasets was examined using the consensus trees from 1000 replicates of ML bootstrapping under the same models, on each locus separately (MasonGamer \& Kellogg 1996). Because no incongruence was detected using a $70 \%$ reciprocal threshold, the two alignments were concatenated and one specimen (Placynthium garovaglioi AL148) for which we have only the mtSSU sequence included. The concatenated alignment was deposited in TreeBASE (accession number S18034).

Phylogenetic relationships and confidence were inferred on the combined dataset using ML and Bayesian inference (B). For the ML analysis, the same settings were used as in the individual gene analyses using GARLI v.2.0, with the same models specified for each partition, for both $\mathrm{ML}$ search and ML bootstrap analyses. The Bayesian inference of the phylogeny was carried out by a Metropolis coupled Markov chain Monte Carlo (MCMCMC), as implemented in MrBayes 3.2.3 (Ronquist et al. 2012). The substitution models estimated using the AICc implemented in jModeltest v.0.1.1 were GTR+I+G (Tavaré 1986) for $\mathrm{mtSSU}, \mathrm{SYM}+\mathrm{I}$ (Zharkikh 1994) for $\mathrm{Mcm} 7$ first codon position (MCM7_c1), F81+I for $M \mathrm{~cm} 7$ second codon position (MCM7_c2), and $\mathrm{K} 80+\mathrm{G}$ for $\mathrm{Mcm} 7$ third codon position (MCM7_c3). The prior distributions settings were: all topologies equally probable and branch lengths followed an unconstrained gamma distribution $(1,0 \cdot 1,1,1)$; the state frequencies followed a $(1,1,1,1)$ Dirichlet distribution for mtSSU and MCM7_c2 and were equally probable for MCM7_c1 and MCM7_c3; the rate matrix for mtSSU and MCM7_c1 followed a
$(1,1,1,1,1,1)$ Dirichlet distribution, for the transitiontransversion rates for MCM7_c3 a beta $(1,1)$ distribution and was equally probable for MCM7_c2; when applicable, proportion of invariable sites followed a uniform distribution $(0,1)$. Two parallel runs with four independent chains each were conducted for 20 million generations, with trees sampled at intervals of 500 generations. A burn-in sample of the first 10000 trees was discarded for each run and the remaining trees were used to estimate branch lengths and posterior probabilities (PP). Convergence was monitored with the diagnostic tool provided by MrBayes 3.2.3., including the average standard deviation of splits between runs. All analyses were run in the CIPRES Science Gateway (Miller et al. 2010).

\section{Hypothesis testing}

We specified two hypotheses to be tested. One equals the classification where Placynthium and Collolechia are two separate accepted genera $\left(\mathrm{H}_{0}\right.$ : Placynthium monophyletic excluding Collolechia). The alternative hypothesis $\left(\mathrm{H}_{1}\right)$ corresponds to the case where Collolechia is nested within a paraphyletic Placynthium. In order to contrast the hypotheses, we calculated Bayes factors by comparing the ratio of the marginal likelihoods of each hypothesis. One common approach is to estimate the marginal likelihoods from constrained and unconstrained Bayesian analyses (e.g., Nelsen \& Gargas 2009; Otálora et al. 2014; Westberg et al. 2015). Here, however, we followed the novel approach proposed in Bergsten et al. (2013), in which the marginal likelihoods are calculated from two alternative topologies after the specification of equally informed priors (constraints). Interpretation of Bayes factor values followed Kass \& Raftery (1995). We calculated the marginal likelihoods using the stepping-stone sampling algorithm implemented in MrBayes 3.2.3., which has proved to be a more accurate estimator of the model likelihoods than the harmonic mean estimator calculated in the MCMC output (Ronquist et al. 2011; Bergsten et al. 2013). We ran the stepping-stone sampling taking 50 steps for a total of 10200000 generations, sampling every 100th generation, and discarding the first 200000 generations as burn-in. The contribution to the marginal likelihood in each step was estimated from a sample size of 2000.

\section{Results}

New sequences from two loci were produced for the 19 specimens, except for Placynthium garovaglioi AL148 for which only $\mathrm{mtSSU}$ was obtained. These were aligned with 10 sequences from five taxa representing several families of the order Peltigerales (i.e., Collemataceae, Lobariaceae and Pannariaceae), retrieved from GenBank. Lobaria pulmonaria was selected as outgroup to root the tree. 
Voucher information for newly produced sequences and accession numbers are listed in Table 1. The matrix of aligned sequences included 1588 sites (635 for $\mathrm{Mcm} 7$ and 953 for $\mathrm{mtSSU}$ ), which was reduced to 1311 sites (of which 297 were parsimony-informative) after the exclusion of the flanking primer regions, introns, and ambiguously aligned regions.

The most likely tree from ML (Fig. 2) with $\ln$ likelihood $=-6126 \cdot 8160$ recovered a topology with 22 resolved internodes, of which 17 were significantly supported (i.e., $\mathrm{ML}-\mathrm{BS} \geq 70 \%$ ). In the Bayesian analysis, the value of the standard deviation of splits between runs was 0.000632 , below the threshold of 0.01 established for convergence (Ronquist et al. 2011). This was further confirmed as the PSRF of all parameters and bipartitions was close to $1 \cdot 0$. The $50 \%$ majority-rule consensus trees of the 60000 trees showed 21 resolved internodes, of which 14 were significantly supported ( $P P \geq 0.95)$. As the topologies had no significant conflicts, only the ML tree is shown in Fig. 2, with the support indicated for both analyses. In both phylogenetic analyses, Collolechia was recovered as monophyletic with strong support $(\mathrm{BS}=95 \%, \mathrm{PP}=1 \cdot 00)$, and nested within Placynthium (BS $=99 \%, \mathrm{PP}=1 \cdot 00$ ).

The two independent runs for each stepping-stone MCMC sampling conducted to calculate the marginal likelihood of each alternative topology reached convergence, as shown by the values of split frequencies $<0 \cdot 01$. The estimation of the marginal $\log$

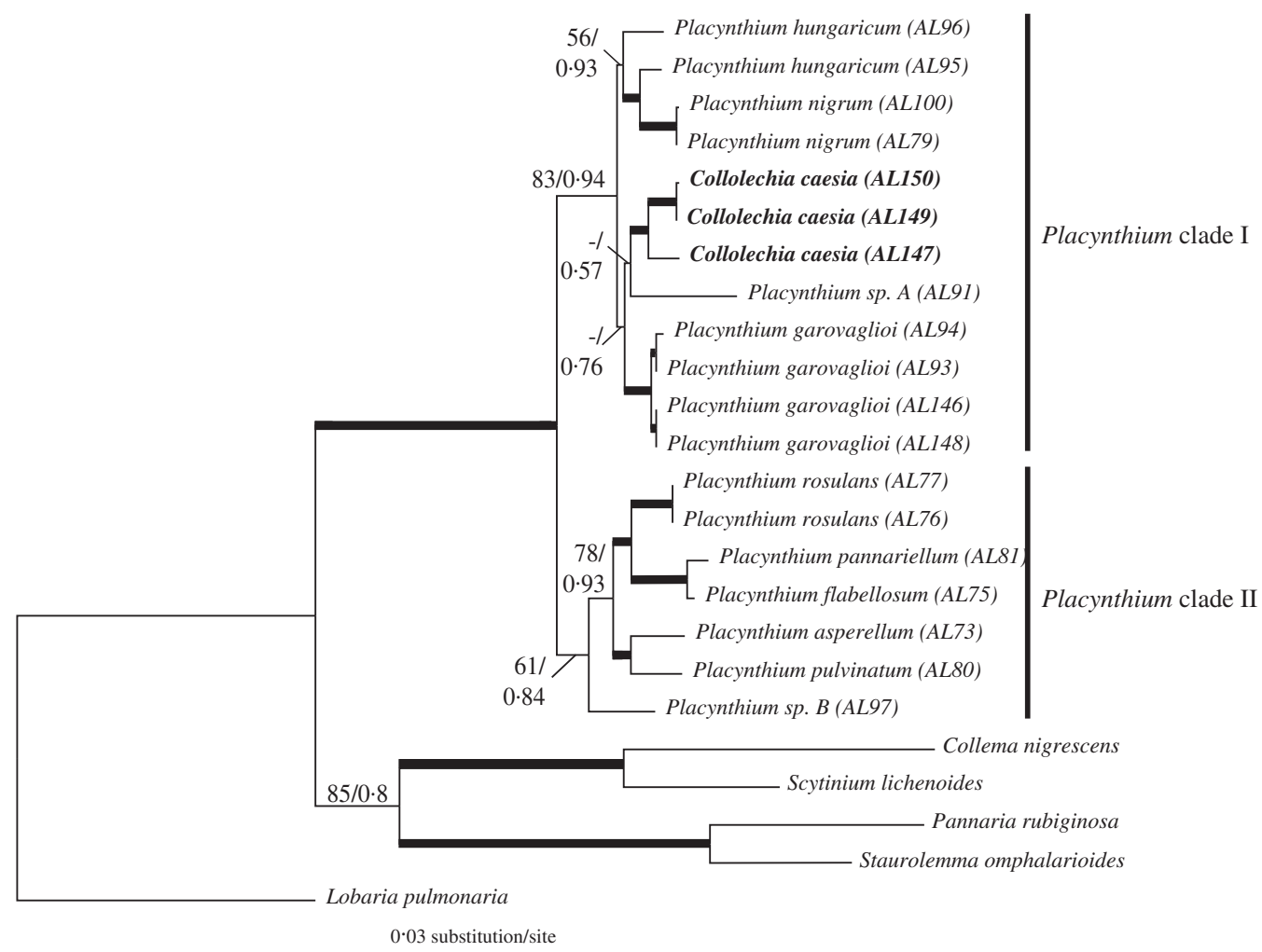

FIG. 2. Most likely tree (ln likelihood $=-6126 \cdot 8160$ ) based on a combined matrix of $\mathrm{mtSSU}$ and $\mathrm{Mcm} 7$ showing Collolechia nested within Placynthium. Internodes with bootstrap values $\geq 70 \%$ and posterior probabilities $\geq 0.95$ are represented by thick lines. Numbers above other internodes indicate ML bootstrap support (only when values $\geq 50 \%$ ) followed by posterior probabilities (only when values $\geq 0 \cdot 5 \%$ ) for the Bayesian analysis. 
likelihood was -6123.60 for the hypothesis in which Placynthium was constrained to be monophyletic and -6114.30 for the alternative hypothesis in which Collolechia was nested within Placynthium. The Bayes factor value was $18 \cdot 6$. We compared this value to the reference table provided by Kass \& Raftery (1995, p.777) that states $2 \times \log _{\mathrm{e}}\left(\mathrm{BF}_{10}\right)$ values $>10$ as strong evidence against $\mathrm{H}_{0}$.

\section{Discussion}

Here, we show that Collolechia is clearly nested within Placynthium (Fig. 2), which is composed of two monophyletic subgroups, one of which contains both Collolechia and the type species of Placynthium, $P$. nigrum, as well as $P$. garovaglioi, $P$. hungaricum, and the potentially undescribed Placynthium sp. A. As a consequence, Collolechia caesia should be classified in Placynthium. The nomenclature of "Collolechia" caesia is complicated, but fortunately Jørgensen (2005) has clarified the situation and the reader is referred to this work for details regarding author citation, typification, and synonymy. When treated in Placynthium, the correct name for this species is Placynthium caesium (Fr.) Jatta.

\section{Placynthium caesium (Fr.) Jatta}

Syll. Lich. Ital.: 38 (1900).-Lecidea contigua var. caesia Fr., Lich. Eur.: 302 (1831).-Collolechia caesia (Fr.) A. Massal. Geneac. Lich.: 7 (1854); type: (France) Gallia merid., Dufour (UPS! - lectotypus, designated by Jørgensen 2005).

This re-synonymization contradicts the suggestion by Jørgensen (2005), who justified treating the two genera as distinct based on their different ascus, spore and thallus characteristics. The ascus characters are difficult to study in many Placynthium species; the asci are small and the structures indistinct, and the variation between ascus developmental stages within one hymenium is frequently quite confusing. We can still confirm that several Placynthium species do have a tube structure in their asci, a trait considered characteristic of "Collolechia" (Jørgensen 2005). Placynthium caesium, P. garovaglioi, P. hungaricum, Placynthium sp. A, and P. nigrum (the type of Placynthium) have a distinct amyloid tube structure in the ascus apex (Fig. 3). Spribille \& Muggia (2013) provided a very useful overview of the ascus structures in Peltigerales, and included the amyloid tube structure in the Micarea-type. A tube structure is reported in a number of Placynthium species by Keuck (1977) and Czeika \& Czeika (2007), and in the Collemataceae (Rambold \& Triebel 1992), and hence could be seen as a synapomorphy for the Placynthiaceae and Collemataceae (Wiklund \& Wedin 2003). The tube in Placynthium is frequently flaring and the apical opening is often visible only from above (Fig. 3A). Our observations confirm that other Placynthium species sampled here (i.e. $P$. asperellum, $P$. flabellosum, and $P$. rosulans) have an amyloid cap-like structure (Fig. 3D), corresponding to the Vahliella-type of Spribille \& Muggia (2013), as previously reported by Keuck (1977) and Spribille \& Muggia (2013). The asci in the potentially undescribed Placynthium sp. B were very difficult to interpret and we await more material to study this further. We have not found any apothecia in the samples of $P$. pannariellum and $P$. pulvinatum, both of which are very rarely fertile. Although we have only investigated a fraction of the species in Placynthium, each ascus character state is correlated with one of the two monophyletic groups identified within the genus. This, however, needs further study to confirm.

All investigated samples of Placynthium caesium and $P$. garovaglioi have long spores (c. $26-38 \times 3-5 \mu \mathrm{m}$ in $P$. caesium and c. 24 $35 \times 3.5-6.5 \mu \mathrm{m}$ in $P$. garovaglio $)$ with $3(-5)$ septa. The difference in spore length between the two species appears less conspicuous than proposed by Jørgensen (2005). Long, pluriseptate spores are also produced in several other Placynthium species, and in our material, P. flabellosum, P. rosulans, and Placynthium sp. B have more than one septum. Placynthium pulvinatum which is shown here (Fig. 2) to be only distantly related to $P$. caesium is, according to the original description (Øvstedal et al. 2009), another species with long, pluriseptate 

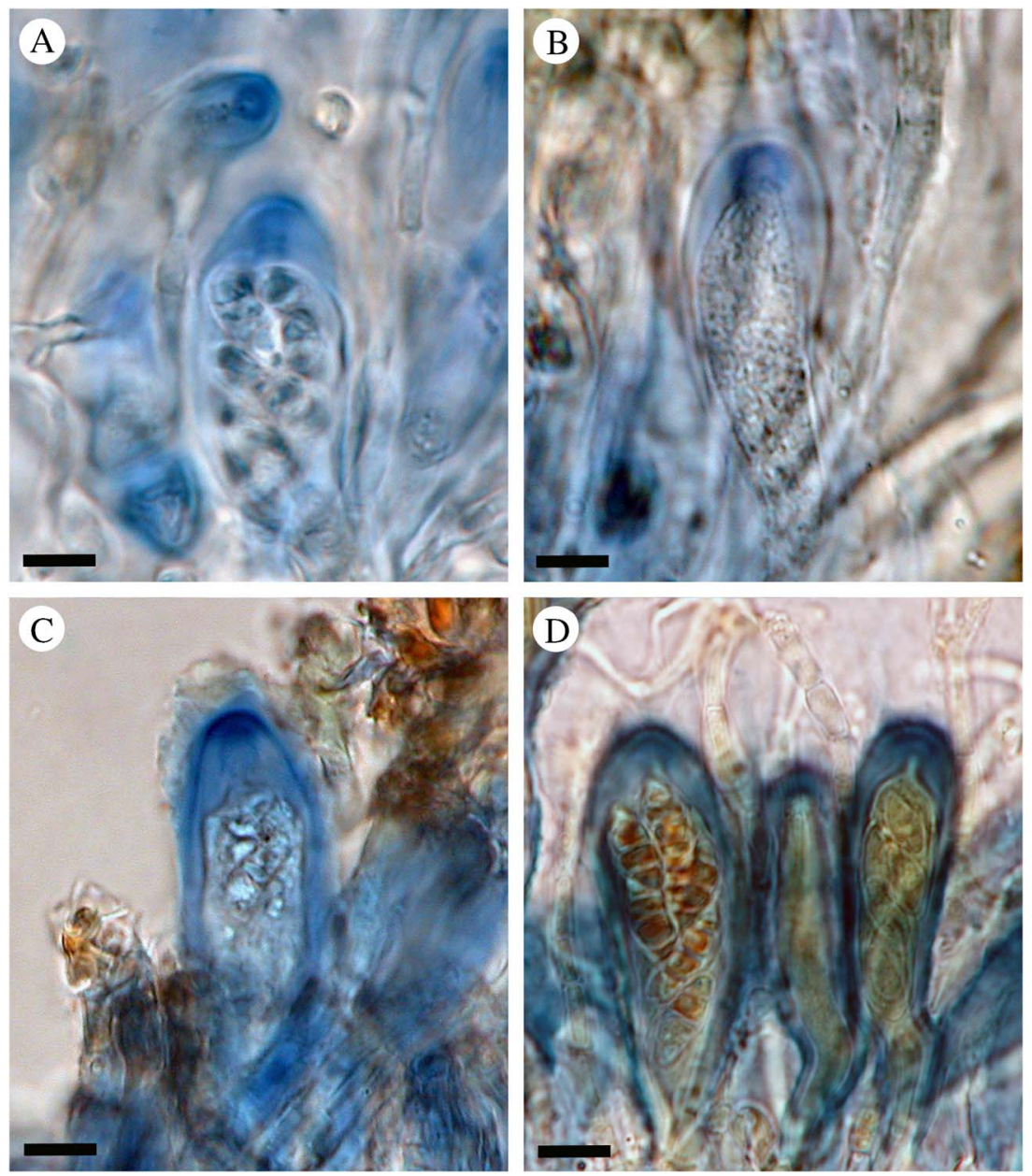

FIG. 3. Ascus characteristics in Placynthium. A-C, tube structures of the "Micarea-type"; D, cap-like structure of the "Vahliella-type". A, Placynthium nigrum, type species of Placynthium (Nordin 5860, UPS); B, Placynthium ("Collolechia") caesium (Košuthová GOT2, S); C, Placynthium garovaglioi (Palice 16954, S); D, Placynthium flabellosum (Nordin 5666, UPS). Scales $=10 \mu \mathrm{m}$. In colour online.

spores, again suggesting that this character state is widespread in the genus. Placynthium nigrum has shorter (c. $10-12 \times 5 \mu \mathrm{m})$, mainly $1(-3)$-septate spores.

In conclusion, when the phylogeny suggests that the two groups are not distinct and the claimed differences in ascus and spore do not hold up to scrutiny, it appears that "Collolechia" caesia should be better treated as a Placynthium species with a crustose-leprose thallus structure. It is not unusual to find examples of closely related lichens, including cyanolichens, which differ in thallus structure. Caloplaca chrysodeta and Micarea leprosula (Tønsberg 1992) are both examples of leprose representatives in greenalgal crustose genera, and the cyanolichen "Moelleropsis" nebulosa was recently shown to be a leprose Fuscopannaria (Ekman et al. 2014). Also, in the spore and ascus characteristics, Placynthium caesium is not unique compared to other Placynthium species and the results of the molecular phylogeny are consistent with the morphology. 
Material investigated (Placynthium caesium): France: Gallia merid., Dufour (UPS L104293, lectotype).Germany: Bayern: ad saxa jurassica prope in valle Wiesentthal Bavariae, Arnold s. n., (S F155260, F155943); Obersdorf (Tiefenbach) in Algäu, Rehm s. n. (S F155268); Streitberg Oberfranken, 1865, (S F15524); Eichstätt, 1956, (S F155248); Muggendorf, Arnold s. n. (S F155266); 1954, (S F155259).--Italy: Massalongo s. n. (S F155283).-Slovakia: Žilinský kraj, Kral'ovany, 1882, Lojka s. n. (S F155283); Muránska planina Mts, Pohronská Polhora - Bánovo, 2014, Guttová E̊ Fačkovcová s. n. (SAV).-Cweden: Gotland: Ardre par., Tviburg (v. Torsburgen), 1943, Degelius s. n. (S F155213); 1963, Degelius s. n. (UPS L159251); Hangvar par., Ire, Floderus (UPS L130317); Irevik, 2014, Košuthová GOT2 (S); Kräklingbo par., Torsburgen, 1857, Stenhammar E Floderus s. n. (S F155224); 1857, Lönnroth s. n. (S F155216, F155217, F155221); 1864, Cleve s. n. (S F155209, UPS L137454); 1871, Molér s. n. (S F155218, S F155215, UPS L137459); 1874, Elmqvist s. n. (S F155225, UPS L137458); 1880, Blomberg s. n. (S F155223; UPS L137452); 1889, Hellborn s. n. (S F155222); 1918, Malme, Malme, Lich. Suec. Exs no 743 (S F155214, UPS L109332); 2014, Košuthová GOT1 (S); Lojsta par., Lojsta, Lönnroth s. n. (S F155210); Lojstabergen, Lönnroth s. n. (S F155934; UPS L137455); Stenkyrka par., Lickershamn, 1869, Laurer s. n. (UPS L137460); Vesterheide par., Hallbros alvar, 1917, Malme (S F155220); 1918, Malme (S F155211); Kneippbyn, 1918, Magnusson 2330 (UPS L160437); Kneippbyn, 2014, Košuthová GOT3 (S).-Switzerland: Schwyz, Pilatus, Hegetschweiler \& Hegetschweiler s. n. (S F155227).-Turkey: Bucak, 2013, Yazici 1037 (S).

Material investigated for comparison (Placynthium garovaglioi): Slovakia: W. Carpathians, Dolina Siedmych, 2013, Palice 16564 (SAV); W. Carpathians, Tisovec, 2013, Palice 16954 (S).-Spain: Navarra: Estella, 1983, Santesson 30775 (UPS L160445).-Poland: Malopolskie: Tatry, Giewont 1954, Tobolewski 76 (UPS L160450).Turkey: Burdur: 2012, Yazici 1123 (S), 1125 (S).

This study was supported by funding from the Swedish Research Council grant 621-2012-3990, to M. Wedin. M. Westberg was funded by the Swedish Taxonomy Initiative, and A. Košuthová was funded by Štefan Schwarz Fund SAS, and EEA and Norway grants no. NF-CZ07-ICP-3-104-2015. We are grateful to the staff at the Molecular Systematics Laboratory at the Swedish Museum of Natural History, in particular Bodil Cronholm, for laboratory assistance. We thank Dr Johannes Bergsten for his helpful discussions and guidance regarding the hypothesis testing analyses. The staff at $S$, SAV, and UPS, and Z. Palice and J. Malíček, are gratefully thanked for the loan of material, and A. Aptroot kindly gave us samples from Turkey.

\section{REFERENCES}

Akaike, H. (1973) Information theory and an extension of the maximum likelihood principle. In Proceedings of the 2nd International Symposium on Information
Theory (B. N. Petrov \& F. Csaki, eds): 267-281. Budapest: Akademiai Kiado.

Bergsten, J., Nilsson, A. N. \& Ronquist, F. (2013) Bayesian tests of topology hypotheses with an example from diving beetles. Systematic Biology 62: 660-673.

Campbell, J., Fredeen, A. L. \& Prescott, C. E. (2010) Decomposition and nutrient release from four epiphytic lichen litters in sub-boreal spruce forests. Canadian fournal of Forest Research 40: 1473-1484.

Cornelissen, J. H. C., Lang, S. I., Soudzilovskaia, N. A. \& During, H. J. (2007) Comparative cryptogam ecology: a review of bryophyte and lichen traits that drive biogeochemistry. Annals of Botany 99: 987-1001.

Czeika, H. \& Czeika, G. (2007) Placynthium in den Alpen und Karpaten sowie in benachbarten Gebieten. Herzogia 20: 29-51.

Ekman, S., Wedin, M., Lindblom, L. \& Jørgensen, P. M. (2014) Extended phylogeny and a revised generic classification of the Pannariaceae (Peltigerales, Ascomycota). Lichenologist 46: 627-656.

Fedrowitz, K., Kuusinen, M. \& Snäll, T. (2012) Metapopulation dynamics and future persistence of epiphytic cyanolichens in a European boreal forest ecosystem. Fournal of Applied Ecology 49: 493-502.

Felsenstein, J. (1981) Evolutionary trees from DNA sequences: a maximum likelihood approach. fournal of Molecular Evolution 176: 368-376.

Gilbert, O. L. \& James, P. W. (2009) Placynthium (Ach.) Gray (1821). In The Lichens of Great Britain and Ireland (C. W. Smith, A. Aptroot, B. J. Coppins, A. Fletcher, O. L. Gilbert \& P. A. Wolseley, eds): 714-718. London: British Lichen Society.

Goward, T. \& Arsenault, A. (2000) Cyanolichens and conifers: implications for global conservation. Forest, Snow and Landscape Research 75: 303-318.

Guindon, S. \& Gascuel, O. (2003) A simple, fast, and accurate algorithm to estimate large phylogenies by maximum likelihood. Systematic Biology 52: 696-704.

Hedenås, H. \& Ericson, L. (2008) Species occurrences at stand level cannot be understood without considering the landscape context: cyanolichens on aspen in boreal Sweden. Biological Conservation 141: $710-718$

Jørgensen, P. M. (2005) Placynthium garovaglioi not present in Scandinavia. Graphis Scripta 17: 3-7.

Jørgensen, P. M. (2007) Placynthiaceae. In Nordic Lichen Flora Volume 3. Cyanolichens (T. Ahti, P. M. Jørgensen, H. Kristinsson, R. Moberg, U. Søchting \& G. Thor, eds): 134-142. Uddevalla: Nordic Lichen Society.

Jovan, S. (2008) Lichen bioindication of biodiversity, air quality, and climate: baseline results from monitoring in Washington, Oregon, and California. General Technical Report PNW-GTR-737. Portland, Oregon: US Department of Agriculture, Forest Service, Pacific Northwest Research Station.

Kass, R. E. \& Raftery, A. E. (1995) Bayes factors. Fournal of the American Statistical Association 90: 773-795. 
Kearse, M., Moir, R., Wilson, A., Stones-Havas, S., Cheung, M., Sturrock, S., Buxton, S., Cooper, A., Markowitz, S., Duran, C. et al. (2012) Geneious Basic: an integrated and extendable desktop software platform for the organization and analysis of sequence data. Bioinformatics 28: 1647-1649.

Keuck, G. (1977) Ontogenetisch-systematische Studie über Erioderma. Bibliotheca Lichenologica 6: 1-175.

Kimura, M. (1980) A simple method for estimating evolutionary rates of base substitutions through comparative studies of nucleotide sequences. Fournal of Molecular Evolution 16: 111-120.

Larsson, A. (2014) AliView: a fast and lightweight alignment viewer and editor for large datasets. Bioinformatics 30: 3276-3278.

Lumbsch, H. T., Schmitt, I., Palice, Z., Wiklund, E., Ekman, S. \& Wedin, M. (2004) Supraordinal phylogenetic relationships of Lecanoromycetes based on a Bayesian analysis of combined nuclear and mitochondrial sequences. Molecular Phylogenetics and Evolution 31: 822-832.

Lutzoni, F., Wagner, P., Reeb, V. \& Zoller, S. (2000) Integrating ambiguously aligned regions of DNA sequences in phylogenetic analyses without violating positional homology. Systematic Biology 49: 628-651.

Mason-Gamer, R. J. \& Kellogg, E. A. (1996) Testing for phylogenetic conflict among molecular datasets in the tribe Triticiae (Gramineae). Systematic Biology 45: 524-545.

Miądlikowska, J., Kauff, F., Högnabba, F., Oliver, J. C., Molnár, K., Fraker, E., Gaya, E., Hafellner, J., Hofstetter, V., Gueidan, C., et al. (2014) A multigene phylogenetic synthesis for the class Lecanoromycetes (Ascomycota): 1307 fungi representing 1139 infrageneric taxa, 312 genera and 66 families. Molecular Phylogenetics and Evolution 79: 132-168.

Miller, M. A., Pfeiffer, W. \& Schwartz, T. (2010) Creating the CIPRES Science Gateway for inference of large phylogenetic trees. In Proceedings of the Gateway Computing Environments Workshop (GCE), 14 November 2010, New Orleans, Louisiana, pp. 1-8.

Nash III, T. H. (2008) Nitrogen, its metabolism and potential contribution to ecosystems. In Lichen Biology, 2nd ed. (T. H. Nash III ed.): 216-233. Cambridge: Cambridge University Press.

Nelsen, M. P. \& Gargas, A. (2009) Symbiont flexibility in Thamnolia vermicularis (Pertusariales: Icmadophilaceae). Bryologist 112: 404-417.

Otálora, M., Jørgensen, P. M. \& Wedin, M. (2014) A revised generic classification of the jelly lichens, Collemataceae. Fungal Diversity 64: 275-293.

Øvstedal, D. O., Tønsberg, T. \& Elvebakk, A. (2009) The lichen flora of Svalbard. Sommerfeltia 33: $1-393$.

Posada, D. (2003) Using Modeltest and PAUP ${ }^{\star}$ to select a model of nucleotide substitution. In Current Protocols in Bioinformatics (A. D. Baxevanis, D. B. Davison, R. D. M. Page, G. A. Petsko, L. D. Stein \& G. D. Stormo, eds): 6.5.1-6.5.14. New Jersey: John Wiley \& Sons.
Posada, D. (2008) jModeltest: phylogenetic model averaging. Molecular Biology and Evolution 25: 1253-1256.

Price, K. \& Hochachka, G. (2001) Epiphytic lichen abundance: effects on stand age and composition in coastal British Columbia. Ecological Applications 11: 904-913.

Prieto, M. \& Wedin, M. (2013) Dating the diversification of the major lineages of Ascomycota (Fungi). PLoS ONE 8: e65576. doi: 10.1371/journal. pone. 0065576

Rambold, G. \& Triebel, D. (1992) The inter-lecanoralean associations. Bibliotheca Lichenologica 48: 1-201.

Rikkinen, J. (2002) Cyanolichens: an evolutionary overview. In Cyanobacteria in Symbiosis (A. N. Rai, B. Bergman \& U. Rasmussen, eds): 31-72. Dordrecht: Kluwer Academic Publishers.

Rikkinen, J. (2015) Cyanolichens. Biodiversity and Conservation 4: 973-993.

Ronquist, F., Huelsenbeck, J. \& Teslenko, M. (2011) Draft MrBayes version 3.2 Manual: Tutorials and Model Summaries. http://mrbayes.sourceforge.net/ mb3.2_manual.pdf. Accessed 27 February 2015.

Ronquist, F., Teslenko, M., van der Mark, P., Ayres, D. L., Darling, A., Höhna, S., Larget, B., Liu, L., Suchard, M. A. \& Huelsenbeck, J. P. (2012) MrBayes 3.2: efficient Bayesian phylogenetic inference and model choice across a large model space. Systematic Biology 61: 539-542.

Scheidegger, C., Groner, U., Keller, C. \& Stofer, S. (2002) Biodiversity assessment tools - lichens. In Monitoring with Lichens - Monitoring Lichens. NATO Science Series. IV. (P. L. Nimis, C. Scheidegger \& P. A. Wolseley, eds): 359-365. Dordrecht: Kluwer Academic Publishers.

Schmitt, I., Crespo, A., Divakar, P. K., Fankhauser, J. D., Herman-Sackett, E., Kalb, K., Nelsen, N. P., Nelson, N. A., Rivas-Plata, E., Shimp, A. D. et al. (2009) New primers for promising single-copy genes in fungal phylogenetics and systematics. Persoonia 23: 35-40.

Schoch, C. L., Sung, G. H., López-Giráldez, F., Townsend, J. P., Miądlikowska, J., Hofstetter, V, Robbertse, B., Matheny, P. B., Kauff, F., Wang, Z. et al. (2009) The Ascomycota tree of life: a phylum wide phylogeny clarifies the origin and evolution of fundamental reproductive and ecological traits. Systematic Biology 58: 224-239.

Spribille, T. \& Muggia, L. (2013) Expanded taxon sampling disentangles evolutionary relationships and reveals a new family in Peltigerales (Lecanoromycetideae, Ascomycota). Fungal Diversity 58: 171-184.

Tamura, K. \& Nei, M. (1993) Estimation of the number of nucleotide substitutions in the control region of mitochondrial-DNA in humans and chimpanzees. Molecular Biology and Evolution 10: 512-526.

Tavaré, S. (1986) Some probabilistic and statistical problems in the analysis of DNA sequences. In Some Mathematical Questions in Biology-DNA Sequence Analysis (R. M. Miura, ed.): 57-86. Rhode Island: American Mathematical Society. 
Tønsberg, T. (1992) The sorediate and isidiate, corticolous, crustose lichens in Norway. Sommerfeltia 14: $1-331$.

Wedin, M., Wiklund, E., Crewe, A., Döring, H., Ekman, S., Nyberg, Å., Schmitt, I. \& Lumbsch, H. T. (2005) Phylogenetic relationships of the Lecanoromycetes (Ascomycota) as revealed by analyses of $\mathrm{mtSSU}$ and nLSU rDNA sequence data. Mycological Research 109: 159-172.

Wedin, M., Jørgensen, P. M. \& Wiklund, E. (2007) Molecular phylogeny suggests the establishment of Massalongiaceae, fam. nov. (Lecanorales, Lecanoromycetes, Ascomycota). Lichenologist 39: 61-67.

Wedin, M., Jørgensen, P. M. \& Ekman, S. (2011) Vahliellaceae, a new family of cyanobacterial lichens (Peltigerales, Ascomycota). Lichenologist 43: 67-72.

Westberg, M., Millanes, A. M., Knudsen, K. \& Wedin, M. (2015) Phylogeny of the Acarosporaceae (Lecanoromycetes, Ascomycota, Fungi) and the evolution of carbonized ascomata. Fungal Diversity 73: $145-158$.
Wiklund, E. \& Wedin, M. (2003) The phylogenetic relationships of the cyanobacterial lichens in the Lecanorales suborder Peltigerineae. Cladistics 19: 419-431.

Wirth, V., Hauck, M. \& Schultz, M. (2013) Die Flechten Deutschlands, Band 1 \& 2 . Stuttgart: Eugen Ulmer.

Zhang, Z., Schwartz, S., Wagner, L. \& Miller, W. (2000) A greedy algorithm for aligning DNA sequences. Fournal of Computational Biology 7: 203-214.

Zharkikh, A. (1994) Estimation of evolutionary distances between nucleotide sequences. Fournal of Molecular Evolution 39: 315-329.

Zoller, S., Scheidegger, C. \& Sperisen, C. (1999) PCR primers for the amplification of mitochondrial small subunit ribosomal DNA of lichen-forming ascomycetes. Lichenologist 31: 511-516.

Zwickl, D. J. (2006) Genetic algorithm approaches for the phylogenetic analysis of large biological sequence datasets under the maximum likelihood criterion. Ph.D thesis, University of Texas at Austin. 